\title{
The Public Manager 2.0: Preparing the Social Media Generation for a Networked Workplace
}

\author{
Ines Mergel \\ Maxwell School of Citizenship and Public Affairs, \\ Syracuse University
}

\begin{abstract}
This article provides the design of a new student-centered information management course to teach the effective use of social media technologies in the public sector as part of public affairs programs. The goal of this "Government 2.0" course is to provide students with analytical and technological skills to navigate the challenges future public managers are facing in a networked workplace. Social media technologies, such as wikis, blogs, microblogging services, or social networking sites, have evolved into innovative channels to collect and share information about government updates and breaking news as well as ongoing operations. Future public managers trained in public affairs programs expect to have access to and work with social media technologies at their future workplace. This course sets out to build competencies and skills to create an increased awareness and knowledge about the effective use of social media technologies for informal learning among government practitioners. Six course elements are identified that support student-centered learning and distributed responsibilities in a combination of online and offline learning experiences. Each course element is discussed, including its learning objectives, related student activities, outcomes, and evaluation elements The article concludes with recommendations for faculty who plan to teach with social media technologies in public affairs programs.
\end{abstract}

The use of social networking services has become a widely accepted channel for government to reach out to its constituents. Public affairs programs have an opportunity to equip their graduates with strategies, techniques, and tactics for understanding and using these technologies effectively and responsibly for their future use in the public sector.

This article describes and analyzes an innovative approach to teaching a new type of information management course using social media tools in a leading Master of Public Administration (MPA) program, titled "Government 
2.0." Social media applications are interactive platforms that allow bidirectional exchanges between government and its diverse audiences (Bretschneider \& Mergel, 2010; Mergel, 2010, 2011). The course addresses the current challenges and opportunities posed by online social networking activities and applies student-centered learning experiences to increase awareness of how government administrators and managers can respond to these challenges. The elements of the course sections are derived from interviews with social media directors in the executive branch of the U.S. federal government and include the following modules: Open Government and the Government 2.0 ecosystem in the United States and worldwide; legal and regulatory bases for the use of social media in government; drivers and barriers for the adoption of social media; access; digital divide and digital literacy; inclusion requirements; transparency, collaboration, and participation; distributed democracy and crowdsourcing; Open Innovation; games, challenges, and prizes; and design elements of social media strategies and policies to fulfill an agency's mission.

The class concept includes pedagogical elements to apply social media applications on three different levels: (a) informal networking: social media tools directly connect students to practitioners and learn from firsthand accounts in real-life situations; (b) class participation elements include the use of social media tools to collaboratively co-create content; and (c) social media services are used to create a culture of constant engagement and social awareness between weekly face-toface meetings. These three elements are used to increase individual skills, but also to empower students to develop necessary skills in an innovative collaborative environment that mirrors the challenges of their future networked workplaces. In many ways this approach is leveling the playing field, and it helps students in all stages of their public service career to understand the usefulness of social media services. The article concludes with recommendations on how to transform knowledge acquired in the classroom into actionable knowledge for the implementation of social media concepts in government, and provides insights for faculty who plan to use social networking services in non-technology classes.

In the following sections, the need for a social media course, the theoretical framework of the course, learning objectives, pedagogical activities, student artifacts, and learning outcomes are explained. Recommendations based on the lessons learned and insights from student evaluations are provided.

\section{Social Technology Usage in the Public Sector Drives the Need for Social Media Education in Public Affairs Programs}

On January 21, 2009-a day after his inauguration-President Obama issued the "Transparency and Open Government" memo addressed to the directors of the departments and agencies in the executive branch of the U.S. federal government (Obama, 2009). The memo was the foundation for the current administration's Open Government Initiative (OGI), and it laid out 
three different areas of government innovation: Government has to become more participatory, more transparent, and more collaborative. It specifically emphasized that agencies had to "harness new technologies" to accomplish these goals.

As the use of innovative social technology practices evolved, more and more obstacles emerged that hindered the initial enthusiasm and slowed down adoption of social media applications. Existing policies mainly regulated the use of standard information and communication technologies, such as e-mail usage, or the use of websites in a static manner-allowing mostly for broadcasting highly formalized and vetted information (McLean, 2005). Websites are infrequently updated and provide limited interaction possibilities for citizens to engage with government.

Several directives and policies to encourage the responsible use of new technologies followed the initial memo and encouraged the use of social media technologies on all levels of government. The General Services Administration and the Office of Science and Technology at the White House defined, for example, social media records management; the Government Accountability Office (GAO) called for directions for social media policies (GAO, 2011); and the General Services Administration (GSA) signed amended Terms of Service Agreements with many social media providers to comply with government standards (GSA, 2010).

The recent use of the microblogging service Twitter during the East Coast snow storms in 2010 (Gregory, 2011), the use of Facebook to coordinate the uprisings of what is now called the Arab Spring in 2011 (Marks, 2011), and the call by the Federal Emergency Management Agency (FEMA) to use social media instead of phone lines to check in with friends and family during earthquakes and hurricanes in late 2011 (Fugate, 2011) all indicate that social media has become a trusted communication channel in the public sector.

Nevertheless, social media applications are challenging and extending the current use of online services in the public sector (Bretschneider \& Mergel, 2010). Traditionally, technology innovations in the public sector were introduced through an executive decision and implemented top down. Social media adoption, however, has taken a different path: So-called intrapreneurs are experimenting with the use of third-party social media platforms and starting to engage with citizens on Facebook, Twitter, or through a weblog. Oftentimes, these experiments are highly informal and only slowly make their way into the formal communication strategy. This adoption behavior is clearly driven by the popular use of social media applications by citizens who are using the platforms to access information or news and connect to their friends and family members, but don't purposefully navigate to government websites (Fretwell, 2010; Kennedy, 2010).

While the initial purpose of social media applications is to help its users socialize by connecting to their off-line contacts in an online environment, social media services have evolved into social sharing environments that government 
can use to extend its existing communication, engagement, and networking mission. Many citizens rely on their trusted friendship network and are vetting official information they hear through their friendship ties. They are paying attention to news and information shared by their trusted online contacts. Social networking platforms have become news validation and social sharing tools that are increasing citizens' awareness for topics they and their friends are interested in. While traditional news sources are valid channels for disseminating government information, social networking sites are additional channels for public engagement and participation as well as increased transparency, which might in turn lead to increased public trust in government operations.

\section{A New Skill Set for a New Generation of Public Managers:} Embracing Public Sector Knowledge Incubation in Unlikely Places

Social media adoption in the public sector is still in its early stages: Many agencies are experimenting with one or two online accounts and highly centralized decision making over the content that is shared. Others only set the context for the use of social media and leave decisions about the type of content to share and the selection of tools up to their subunits, which has resulted in large numbers of decentralized — and oftentimes duplicated — accounts (Mergel, 2010). In this early adoption phase, experimentation happens initially outside the existing routines and regulations, and adoption is spreading slowly.

Recently, Jeffrey Levy, Director of Web Communications at the Environmental Protection Agency (EPA) and cochair of the Federal Web Managers Council, publicly tweeted (Figure 1).

Figure 1.

Jeffrey Levy Twitter update on October 19, 2011

\section{It's not whether we need to use social media, but how. But how is HARD. Simplistic statements don't advance us. \#GovD11}

19 Oct via Twitter for BlackBerry@ 
This act by Levy implies that whether or not to use social media in government is no longer a question; instead, it is a widely accepted practice. However, the tactics and strategies on how to use these new forms of interaction effectively are still unclear to many government professionals.

Therefore, public managers need to be equipped with an understanding of how their diverse set of stakeholders view the usefulness of interactions with government and use engagement channels that support the agency's mission to accomplish these goals. The existing methods and instruments out of the e-government era no longer support the use of social media and tasks, and resources have to be changed to address these challenges.

Given the apparent lack of know-how and formal guidance, social media professionals in government turn to their informal network of peers to understand best practices and make sense of their own actions. The current budget crunch leaves government organizations with little room to acquire innovative tools, consulting practices, or unlimited time for experimentation. Despite the dire budget situation, innovation happens; and social media applications allow public managers to tap into knowledge outside their own organization. Take, for example, the work by Marie Davie, Assistant Commissioner for the Office of Assisted Acquisition Services (AAS) in GSA's Federal Acquisition Service (FAS), who uses social media to improve the federal acquisition process (Goodnoe, 2005). Davie turned to her peers represented on the social networking site GovLoop.com for a crowdsourcing experiment. Together with knowledge specialists in government, journalists, academics, and industry representatives, she started the discussion in an online group called "Acquisition 2.0." The result of this open ideation process was the BetterBuy Wiki-a collaborative content creation platform that helps government to improve the specifications of requests for proposal (RFPs) before they are opened for submissions (Veen, 2009).

Davie was able to tap into the informal knowledge her peers were willing to provide to her on third-party platforms, thus crowdsourcing innovative ideas outside the official government context. She used her informal networking skills to create an experiment that bridged the different user groups that are not directly connected to each other and so crossed structural holes in her network (Burt, 1992). Moreover, she activated knowledge of those actors in her network that are not part of the formal federal acquisition process.

Similarly, government professionals are using informal networking on other social media channels: On the microblogging site Twitter.com, government professionals are using the hashtag \# localgovchat (Twitter users meet every Wednesday at 9 p.m. EST online to talk about local government topics) or \#CMGR for community managers to discuss social media challenges. They are participating in LinkedIn discussions groups, such as "Gov 2.0—Technology, Initiatives and Innovations." These examples highlight how government 
professionals use social media to incubate knowledge that is not readily available within the bureaucratic hierarchical knowledge base of their own organizations. Instead, they have developed new forms of collaborative capacity to access information beyond organizational boundaries and accept innovative information from outside of government (Bughin, Hung Byers, \& Chui, 2011). This form of informal learning among practitioners using social media poses risks but also opportunities for government to access innovative insights.

The skill set of future public managers therefore needs to include innovative forms for informal learning and networking among government professionals outside of their own organization and rather formalized information sharing procedures. To achieve this goal, public affairs programs need to provide skills that include

- new forms of digital competencies,

- new forms of collaborative capacities, and

- new forms of social and digital awareness to mitigate the risks for each participant not just individually but also for the organization as a whole.

\section{Challenges for Public Affairs Programs to Prepare Students for the Connected Workplace}

Future graduates are facing challenges in their preparation to become the next generation of public managers. While most of them will most likely start as analysts, researchers, or in support staff functions, they will later on become leaders and managers with the ability to allocate and distribute resources. Most information management syllabi in the top 50 public affairs schools provide programming skills for database management, website programming skills, or applied exercises of geographic information systems (GIS) applications, leaving little room for the current trend of social media usage in the public sector.

When students transition from their mostly personal use of social media applications to a professional environment in which social media, or for that matter Internet access in general, is highly restricted, future employers will face a brain drain from government to other sectors. Take for example government DNA labs that have only one web-enabled computer that is in the hallway and restricts all private access to the Internet, and thereby pushes their employees to communicate with their peers in their free time on their private computers (Mergel, Lazer, \& Binz-Scharf, 2008).

The fast pace of change in technology usage in the public sector has also taken public affairs programs by surprise. Faculty members are rethinking class design and practices as well as analytical skill sets that future public managers have to acquire in order to be competitive on the job market. A recent survey among college students conducted by Cisco found that approximately $56 \%$ of current graduates are not willing to accept a job from an organization that bans social media, or they will circumvent existing policies (Kamentz, 2010). 
Two thirds of college students will ask about social media policies during their job interviews. The expectations of future employees show a trend toward absolute freedom to use social media at the workplace and even the liberty of unrestricted access to their personal social media accounts. These prospects are met with employers' concerns to mitigate the risk that social media poses for the workplace, keep authority over content, and comply with existing information sharing and creation processes.

The question therefore is, how can public administration as a teaching discipline embrace the challenges of an ever-changing social media landscape and at the same time balance the expectations of students and employers? Unless both public affairs programs and government continue to make the shift toward an integrative approach of social media, they might lose valuable parts of the future workforce to other sectors.

\section{Course Design: A Student-Centered Learning Environment to Develop Informal Practitioner Learning Experiences}

Learning processes are as diverse as they are individual. Generally, research has shown that students learn about $10 \%$ of the relevant and actionable knowledge through facts that come to them in form of formally assigned readings or lectures that are delivered to them. Both elements are passive forms of learning; the students have to make sense of the content by themselves and combine it with their existing experiences and knowledge base.

The course's pedagogical framework focuses on student-centered learning (C. Estes, 2004; Motschnig-Pitrik \& Holzinger, 2002; O’Leary, 1997, 2002). All in-class activities, as well as the assignments between face-to-face classroom meetings leading up to the final implementation plan, concentrate on the students' learning experiences.

The course applies a combination of traditional classroom elements and online learning experiments to accomplish the objectives. First, the assigned readings include foundational articles on the use of technology in the public sector (for a list of all required readings per class, see the full syllabus in the appendix). The topics were chosen based on problem-driven themes that bridge multiple disciplines, and the students are asked to apply known information management concepts to the new and innovative use of social media in the public sector. The traditional readings are complemented by contemporary readings from social media-related blogs, government technology press coverage, and other related news coverage. Table 1 shows the course outline. The topics are divided into three main application areas: (a) underlying mechanisms for the use of social media; (b) making social media work in government; and (c) student projects. 
I. Mergel

Table 1.

Course Outline

\begin{tabular}{|c|c|c|}
\hline Week & Topics & \multirow{8}{*}{ 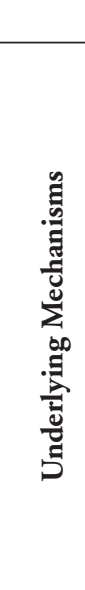 } \\
\hline 1 & $\begin{array}{l}\text { Course overview, syllabus review, course requirements } \\
\text { Introduction to Government } 2.0\end{array}$ & \\
\hline 2 & The social media ecosystem & \\
\hline 3 & Barriers and drivers for the adoption of social media & \\
\hline 4 & Organizational institutions & \\
\hline 5 & America 2.0: "It's no longer the campaign" & \\
\hline 6 & Social media policies and strategies in the public sector & \\
\hline 7 & Social media records management and risk mitigation & \\
\hline 8 & Reuse of public sector information and mobile applications & \multirow{5}{*}{ 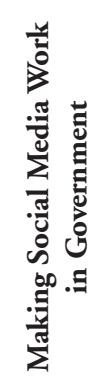 } \\
\hline 9 & Democracy 2.0: Distributed democracy online & \\
\hline 10 & Open Innovation in the public sector & \\
\hline 11 & Collaboration 2.0 across boundaries & \\
\hline 12 & Measuring social media impact & \\
\hline 13 & The future of social media in government & \multirow{3}{*}{ 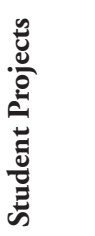 } \\
\hline 14 & Final class project presentations (Part I) & \\
\hline 15 & $\begin{array}{l}\text { Final class project presentations (Part II) } \\
\text { Wrap up }\end{array}$ & \\
\hline
\end{tabular}

In addition to the readings, the students are asked to participate in ongoing peer-to-peer dialogues. This is accomplished with the help of different collaborative online environments (Orlando, 2011). In the four years of teaching the class, several different types of wikis were used. One year, a wiki for educational purposes was used by the students to work collaboratively on weekly class assignments, and it provided an online space to collect ideas and material for their final projects. In another year, students used Google Wave to share articles, comment on each other's posts, or prepare questions for future guest speakers. The speakers were then invited to browse through the questions ahead of time as a way to prepare for the class meeting. This approach has helped both guest speakers and students get to know each other ahead of time, start informal 
conversations, and open a communications channel for future professional networking (Neubauer, Hug, Hamon, \& Stewart, 2011). The platforms were used throughout the semester and beyond the duration of the program for the students to expand their conversations and carry out learning experiences without being bound to the classroom setting.

Guest speakers are scattered around the country and even abroad. They are connected live with the class via the voice-over-IP (VoIP) telephony service Skype or Google Video Chat (depending on their local computer access). For the classroom setup, a computer with the ability to use third-party services is required. Note: Not all university computers allow Skype, due to potential bandwidth risk and other security concerns. In addition, an external web camera is necessary for bidirectional video sharing and to gain the flexibility of moving the camera around in the room to allow students to interact with the guest speakers. An external microphone and speaker set for pristine voice quality is necessary for the interactive Q\&A sessions. Figure 2 shows Noel Dickover, who is responsible for building the in-house wiki platform DODTechipedia and is cofounder of CrisisCommons.org and consultant to the eDiplomacy group at the U.S. State Department. At the time of his virtual guest lecture, he was on assignment in Latvia organizing the TechCampGlobal meeting as part of the State Department's Civil Society 2.0 project.

Figure 2.

Guest Speaker Joining Government 2.0 Class via Skype Video and Screen Sharing

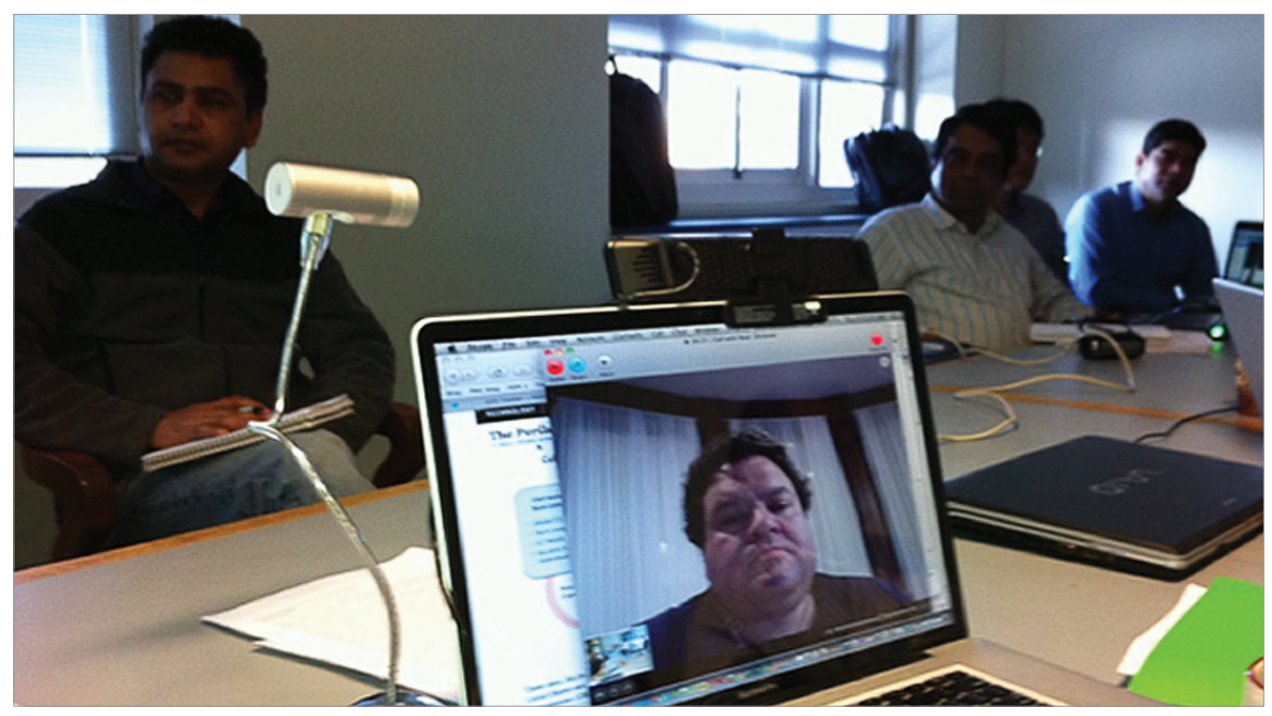

The following subsections describe the teaching strategy, the online learning experiences, student outcomes, and their evaluation for the six main themes of the course. 


\section{Increasing Digital Literacy and Online Competency}

Students need to learn how to use social technologies to fulfill the mission of their organization. Professionally they need to learn how to balance their professional, personal, and institutional loyalties and how they represent themselves and their organization in digital environments. At the same time, the course aims to raise an awareness of how the use of social technologies can help increase a government's organization transparency and accountability among all of its audiences.

The technological features of most social technologies allow for a reflexive feedback cycle. This means that as soon as government starts to engage on social media sites, citizens have increased expectations of reciprocity. Commenting might occur in the form of a constant back-and-forth between government and citizens, thus increasing the expectation of near real-time feedback. This feature results in publicly observable, direct interactions between government and citizens.

In this class, the students are therefore required to immerse themselves in a variety of tools to be able to experience not only the design features but also cultural aspects and emerging online memes. All students have to select a social technology and prepare a hands-on workshop for their peers in the classroom. The presenting students are instructed to point out the shortcomings and risks the tools might pose for government operations. The exercise helps to start discussions about potential conflicts between audience expectations and the government's standard operating procedures. The learning outcome gives students the opportunity to take the standpoint of a government professional and therefore look beyond their personal use patterns. The class then evaluates the learning experience and actively provides peer-to-peer feedback to the "teacher."

The procedural learning component is accompanied by an individual writing task: To accomplish full immersion, students are required to start writing for digital environments. The online engagement component includes a minimum of five 350-word blog posts per semester. The challenge for this task is very real: The experience of this 4-year-old course shows that students jump to the conclusion that they will never get their future (or past) top management to start blogging or tweeting. While there is usually a lot of initial resistance, especially from more experienced Executive MPA (EMPA) students, each week students have to follow a specific task to learn how to be part of ongoing online conversations.

Online writing experiments are scaffolded: Students start with a relatively small workload by sharing links to interesting online content that is relevant to the course topics. In a next step, they are asked to comment on other students' 
links or provide insights from their own professional experiences to postings by other students. This "Link—quote—comment" process allows distributing the workload across many shoulders, and the students still experience all elements of social technologies: They are writing for the web, receive comments, and immerse themselves in online conversations, and as a result gradually become more comfortable with making their own contributions. Students are encouraged to change their writing style to comply with the new Plain Language Act of 2010 (P.L. 111-274, 2010), which directs government agencies "to improve the effectiveness and accountability of Federal agencies to the public by promoting clear Government communication that the public can understand and use." The writing exercises increase the students' comfort level, so that they are then willing to post questions on the class blog for the practitioners joining the classroom (http://gov20class.blogspot.com/).

In summary, the online writing components include teaching a social media tool to the class, creating and sharing content online, engaging in online conversations, and direct peer feedback. Ten percent of the grade is based on online engagement (blogging and tweeting), and $20 \%$ of the grade constitutes the tool presentations and active classroom participation, including commenting and providing feedback to other students.

\section{Creating Social Awareness: Inclusiveness and Accessibility}

Online interactions pose important challenges on the notion of inclusiveness versus exclusiveness. Students need to be able to evaluate which social media technologies allow for the maximum level of compliance with Section 508 of the Rehabilitation Act. The act directs federal agencies to acquire electronic and information technology that is accessible for persons with disabilities (for more information, see Section508.gov). The goal of the digital literacy experiment is to make students aware of the traditional viewpoint of the dichotomous value of the digital divide (either you have access or you don't) and demonstrate to them the difference that continuous digital access makes (Mergel, 2011). Access in the U.S. context has mostly been defined as convenience, such as the time, location, and speed of access to digital information: Instead of working on their own laptop, people might have to go to a community center or library to get access; they have a dial-up connection instead of a convenient broadband connection; or access is limited based on a government agency's rules of access to private social networking accounts (Mergel, forthcoming 2012).

To help students understand the limitations of social technologies in terms of inclusiveness, but also to increase their awareness of their own degree of digital literacy, I designed an interactive classroom experiment (Box 1). 
Box 1.

Experiment: Digital Literacy for GenY and GenX Students

The experiment starts out with children's birthday sunglasses: Each student receives a pair of plastic glasses that can be found in the birthday aisle of department stores. In addition, they receive cotton swabs and a tinted skin cream (preferably Vaseline) to smear on the front of their glasses. After this is done, students are asked to read what was recently posted on their class Facebook group page. While this feels like a kid's birthday party at the beginning, the students are usually stunned when I ask them what they are able to read. Answer: "Nothing." Then the students are asked where the button is located on Facebook, Twitter, or YouTube to help them read or hear the content. Answer: "Don't know? Is there one?" In a third round, the students are asked to use earplugs in addition to their Vaseline-smeared sunglasses and attend one of the online Town Hall meetings that are streamed live on YouTube or Facebook video. Again, they are asked what they hear, and if there are any alternative ways to access the information they just missed.

The point of this experiment is to help students understand that none of the popular social networking sites seems to be intuitively compliant with Section 508 of the Rehabilitation Act to give citizens with disabilities equal and instant access to digital information that government is posting online. One of the points my students made was that governments usually operate with limited resources and do whatever they can to cater to the majority of citizens and that unfortunately there might not be enough resources to find solutions for minorities. This activity is a great conversation starter to help students think through alternative display functions and ways to deliver government information to all audience members.

Here are the main takeaways from the experiment: (a) Most of the popular social networking sites that are promoted in government are not compliant with

Figure 3.

Digital Literacy Training
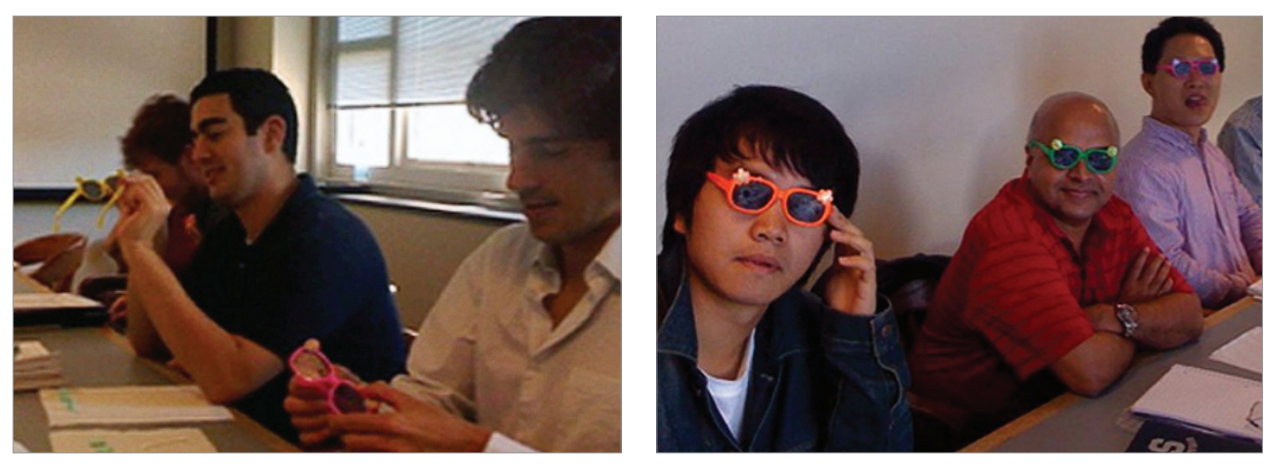
Section 508 of the Rehabilitation Act, and it is extremely difficult for screen readers and other aids to navigate sites like Facebook (Twitter is an exception because it is solely text based); (b) Social networking sites might increase the digital divide, leaving people behind who could hugely benefit from tapping into networks that can help them connect to government, help each other and share information within like-minded communities; (c) What seems to be highly convenient for students on university campuses (24-7 free wireless access) is not the reality for most citizens. A discussion that includes international students from developing countries will help American students to understand this point. As one of the EMPA students from Nepal recently pointed out: " 14 hours of the day we don't have electricity! High-speed Internet connectivity is nothing we can experience." Figure 3 shows the students in the classroom wearing tinted glasses.

\section{Understanding and Mitigating Online Risks}

Using social technologies for professional purposes will involve many risks and challenges for future government officials. As an example, for an unexpected use of social technologies, public employees tweeted bank closing decisions from their personal Twitter accounts before the official decision was announced by the regulating agency. This event mostly highlights the low awareness of how the social graph (all friends-of-friends' connections) helps to snowball messages through wider parts than just the network of direct contacts. Increasing digital literacy skills therefore serves a second purpose: It helps mitigate and potentially reduce the risks associated with the use of social media in the public sector (Bart, 2011a; Oxley, 2011). As a result, Macon Phillips, current Social Media Director in the Executive Office of the President, maintains two different Twitter accounts. On the left in Figure 4 is his official professional and public Twitter presence (@macon44), and on the right is his private—and locked—Twitter account (@macon).

Figure 4.

Private Versus Professional Digital Profile
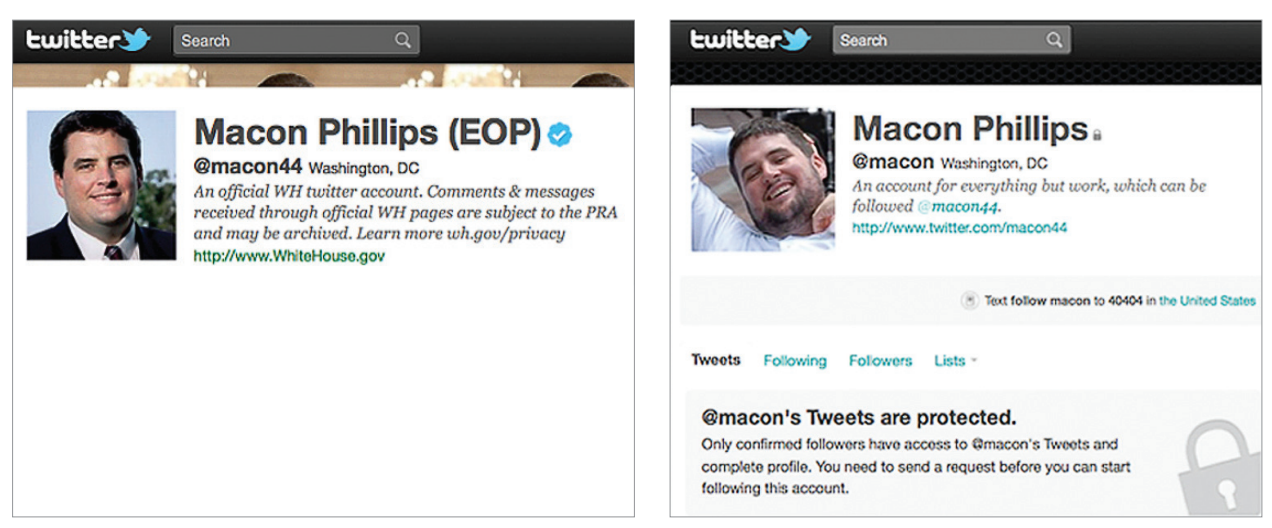
As a teaching element, the students receive the assignment to analyze existing social media policies in the public sector to understand the risks and expectations of public employers. The exercise creates an increased awareness of existing rules and regulations that government agencies have already adopted to mitigate social media pitfalls (Bart, 2011a, 2011b). For example, the U.S. Army has recently extended the rules for social media use and is now also aiming to raise awareness about responsible and safe use of social media beyond servicemen to family members (A. C. Estes, 2011). A list of social media policies is available on my blog at http://inesmergel.wordpress.com/social-media-policies/.

Part of a risk mitigation strategy is also to understand what constitutes a government record and how these records have to be managed (Franks, 2010). Future government employees have to be able to distinguish between records that are subject to archiving regulations and those records that are not scheduled for archiving. While many social media records so far are not immediately scheduled for archiving, the students learn in this section to think about alternative means of saving or replicating online content, so that records are easily accessible after online services might shut down or not make records available anymore.

The in-class activities are accompanied by two written assignments: First, students are required to submit a memo outlining the elements of an organizational social media strategy. In a second memo, they have to write a personal statement that interprets their individual social media strategy for their transition from mostly personal interactions to professional online interactions. The assignments account for $20 \%$ of their grade and are discussed in class, and the students receive written feedback from both the instructor and their peers.

\section{Analytical Competencies}

Measuring the impact of social media practices is a crucial element of the course and has also evolved in daily government practice as an important indicator of success for social media actions. The students are asked to evaluate the executive departments in the U.S. federal government in form of a web content analysis exercise: Each department is listed with all its members' social media accounts, and the students analyze each department's social media activities. The task is broad enough to leave room for each student to first individually extract meaningful insights. In class, a moderator is chosen who guides the whole group through a brainstorming exercise to build measures for social media impact. Students contribute their results and then discuss the impact of measures and their individual evaluations. The result is a social media measurement matrix that shows both quantitative measures (e.g., followers, contacts, number of updates, etc.) and qualitative measures, such as type of information shared, type of audience 
members, and number of retweets and reach. This interactive exercise helps the students to reach the insights in a collaborative dialogue.

The course readings, analysis of available online measurement tools and dashboards, and classroom discussions build the basis for the third written assignment. The students are asked to create a "business case" for the use of social media in a government agency of their choice. They use available quantitative data such as followers, likes, and number of comments, in combination with insights from a qualitative analysis of the content of online messages. The business case shows the impact of government social media interactions. The written management memo then provides instructions for top management on how to interpret the results and makes recommendations for future directions.

\section{Designing an Implementation Plan With Integrated Self- and Peer-to-Peer Evaluation}

All course elements have the goal of empowering the students to make informed decisions about the adoption, implementation, and ongoing management of social media tools for a government organization of their choice. They learn about the needs of government audiences, the barriers and difficulties involved in adopting social media tools, and their potential impact. The assignments throughout the course are building students' expertise and empowering them to design a detailed social media implementation plan for a government organization.

First, students learn and teach each other about acceptable social media tools and their potential use for government. Second, they discover appropriate content online and start to share and reuse it. Then they critically assess elements of social media policies and how an organizational strategy differs from their personal social media activities. Lastly, they design an implementation and management plan for a government organization that has clearly not adopted a social media strategy. This exercise reflects practices of social media directors in the U.S. federal government: Each of them experiments with tools and practices they observe online and then builds a business case over time to present to top management in order to access additional resources and get leadership buy-in. The students finally present their plan in class, where they receive feedback and the opportunity to integrate improvements and suggestions into their plan before they send it to the agency. The final implementation plan accounts for $60 \%$ of the overall grade. Students are evaluated by the instructor and receive peer feedback that they can use to improve their final plan.

The teaching plan (Table 2) summarizes the course elements, teaching objectives, content, student activities, artifacts, and assessment tools. 
I. Mergel

Table 2.

Teaching Plan

\begin{tabular}{|c|c|c|c|}
\hline 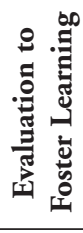 & 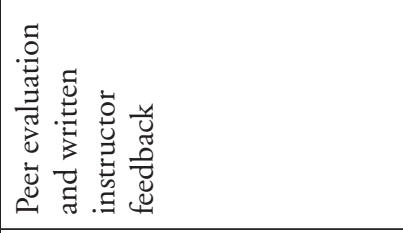 & 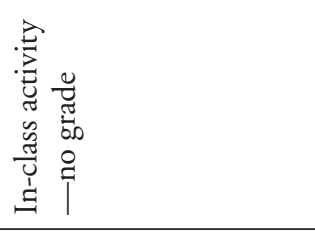 & 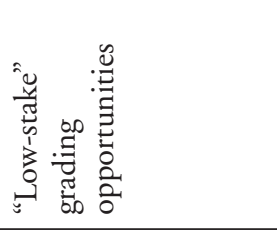 \\
\hline 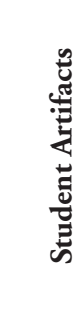 & 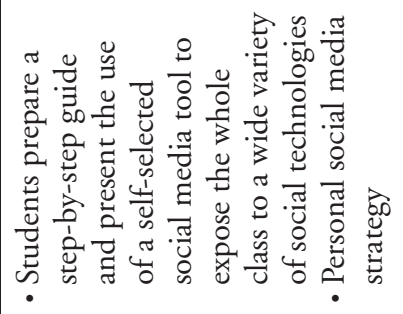 & 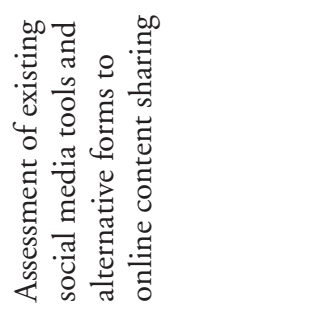 & 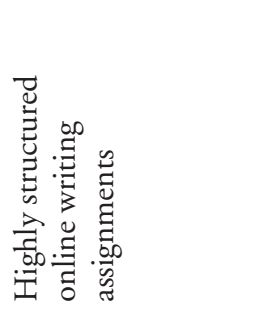 \\
\hline 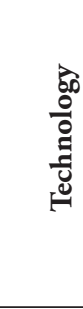 & 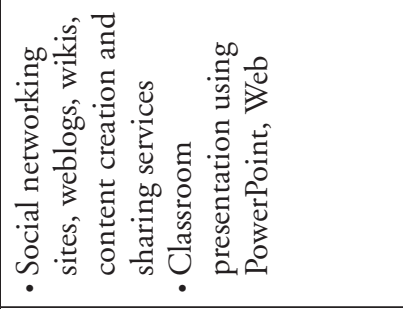 & 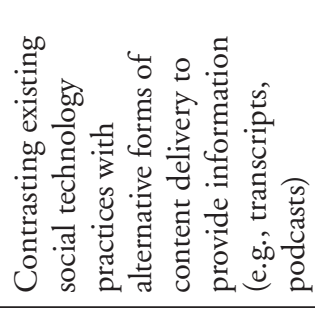 & 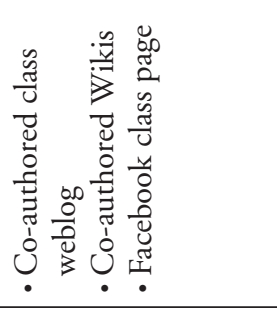 \\
\hline : & 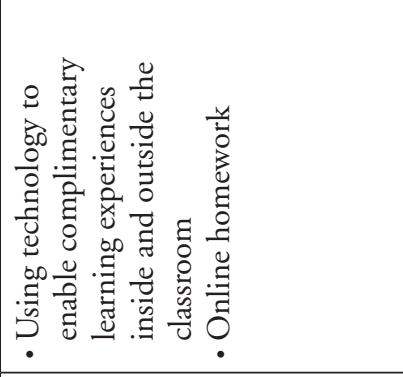 & 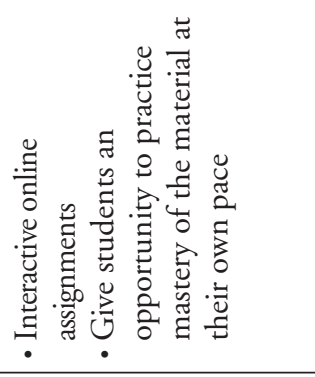 & 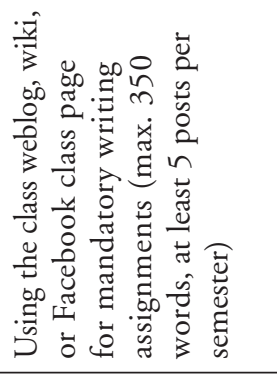 \\
\hline है & 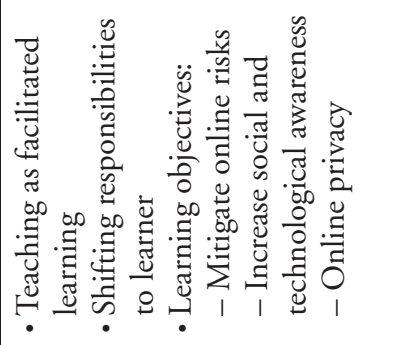 & 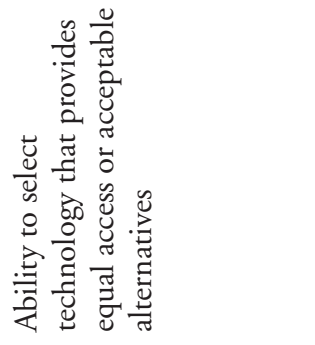 & 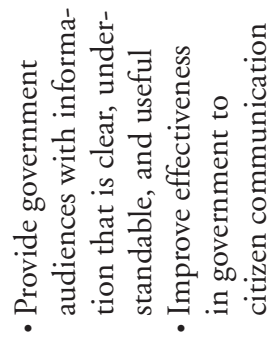 \\
\hline نे & 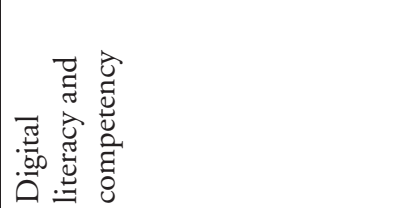 & 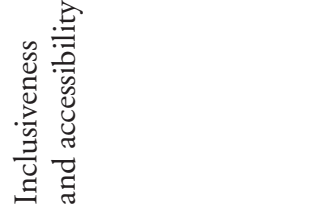 & 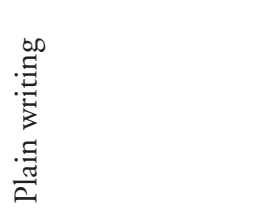 \\
\hline
\end{tabular}

482 Journal of Public Affairs Education 
Table 2.

Teaching Plan (continued)

\begin{tabular}{|c|c|c|}
\hline 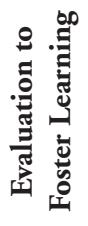 & & 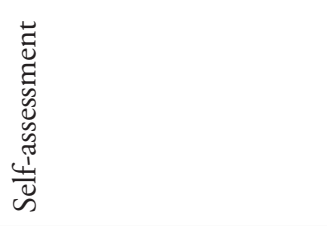 \\
\hline 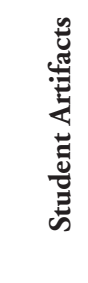 & & 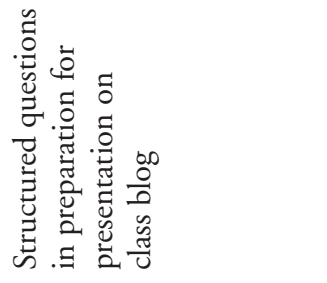 \\
\hline 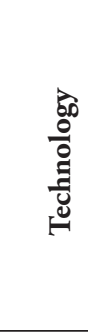 & 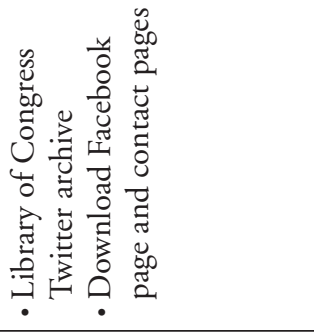 & 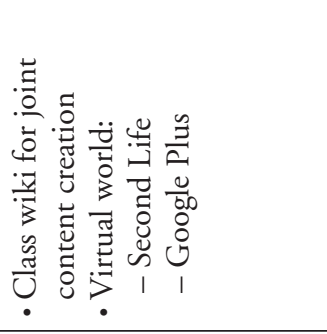 \\
\hline : & 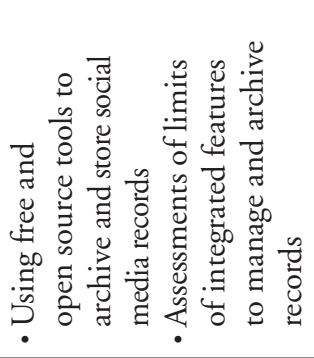 & 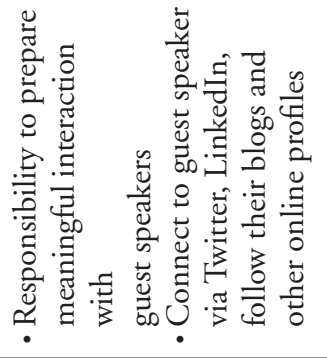 \\
\hline $\begin{array}{l}\text { है } \\
\text { है }\end{array}$ & 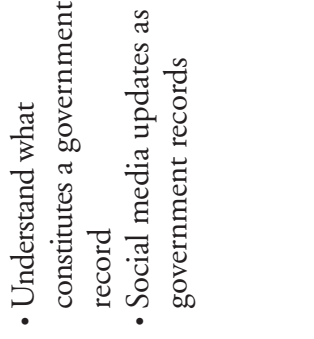 & 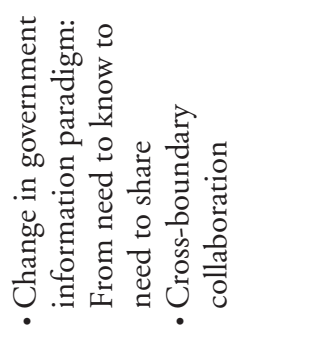 \\
\hline نัّ & 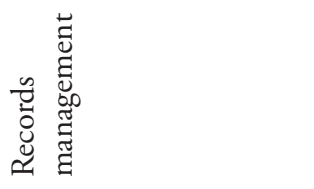 & 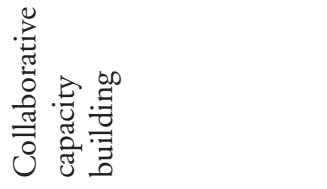 \\
\hline
\end{tabular}




\section{Critical Assessment of Teaching Elements for Student Empowerment}

This newly developed Government 2.0 course is an ongoing experiment to empower students to tackle future challenges of a networked workplace in the public sector. The course combines online and offline learning experiences to create a student- and learner-centered environment in which the participants feel comfortable using social media and interacting with their peers online. The students are empowered to improve their digital competencies and online conversation skills in order to understand the pitfalls of online engagement in the public sector. They immerse themselves in informal practitioner networking-a concept that was recently called for in an article by Schweik et al., who advocate much higher and timely integration of academic and practitioner experiences and insights in the classroom (Schweik, Mergel, Sanford, \& Zhao, 2011).

Students start the class with a diverse set of their personal professional experiences and backgrounds. More experienced EMPA students will find it especially challenging to match the existing press-release government communication style with alternative forms of digital government interaction. For less experienced MPA students, this serves as a learning experience for the flow of strategic conversations they might be participating in at their future workplace.

This class is therefore designed to go beyond the traditional form of teaching topics related to e-government by creating experiences among the students as well as with the involved practitioners. Social technologies are constantly changing, and so are the social behavior and culture of each digital environment. This environment leads to evolving innovative insights, so the class cannot be taught as a repetitive, static topic. For colleagues starting to teach about and with social media, it is important to recognize that there are still very little research and cases available, even though the topic has become a new reality in government.

Students who participated in the class during the last 4 years commented on the structure, the interactive course elements, and their personal learning experiences as follows: "It opened our eyes to a new medium...very important given the events in the Mideast"; "she exposed us to the top people in the field and gave us insight"; "helped me appreciate...citizen participation and collaboration"; "opened our eyes to something we were not aware of"; "course was fantastic and very useful for my future career... she went out of her way to connect me with practitioners in the field and establish myself professionally"; and "[she was] open to discussion of our ideas."

\section{Recommendations for Public Affairs Programs}

Faculty who are tackling the challenge of teaching about emerging issues take risks that go beyond standards set for existing and long-established core classes in public affairs programs. Topics are evolving, and behavior is observable in real time and develops throughout each semester - this can be both a challenge and an opportunity. The opportunity of an evolving topic such as Government 2.0 
is that cases are emerging on a weekly basis and can lead to fruitful insights and discussion in the classroom. Examples include the social media revolutions in Northern Africa in 2011 or the use of social media during presidential campaigns and discussions about their projected impacts on governing operations.

Many of the course features can be applied to non-technology classes in public affairs programs: As an example, faculty can tap into the wisdom of alumni and connect them to their current students by inviting them directly into the classroom via Skype, Google video chat, Google Plus hangouts, or regular videoconferences. To increase the online experience, faculty can use class blogs to increase online writing opportunities, or ask their students to follow Twitter hashtags for ongoing or emerging issues related to the class content. While many faculty use class e-mails - sometimes channeled via digital environments such as Blackboard - to connect and keep students engaged between face-to-face class meetings, social media offers additional opportunities to engage students throughout the whole semester - and even beyond the time-bound duration of a course.

Even though social media applications are offering innovative forms to interact with peers and with the technology itself, online writing as well as informal interactions among students and with faculty members can lead to misunderstandings. Clear boundaries, social media policies, and an online netiquette are necessary to lay the ground rules for responsible and acceptable online practices. This approach will help mitigate the risks for both students and faculty members.

Combining offline teaching activities with interactive social media activities means that faculty members have to spend significant time in setting up a student-centered learning environment. It means that faculty constantly have to immerse themselves in ongoing technology changes and need to recognize their own need for training. It also means that it takes more time to situate and teach students the course objectives and get them up to speed on using the technology in a professional environment. As a result, the students will be engaged throughout the whole semester and not only during the face-to-face classroom meetings. Using social media technologies in public affairs programs empowers students to take on responsibilities in their networked class environment and will prepare them for future challenges in the workplace.

\section{REFERENCES}

Bart, M. (2011a). Understanding the potential pitfalls of social media. Faculty Focus: Focused on Today's Higher Education Professional. Retrieved from www.facultyfocus.com/articles/trends-in-highereducation/understanding-the-potential-pitfalls-of-social-media/ 


\section{Mergel}

Bretschneider, S. I., \& Mergel, I. (2010). Technology and public management information systems: Where have we been and where are we going? In D. C. Menzel \& H. J. White (Eds.), The state of public administration: Issues, problems and challenges (pp. 187-203). New York: M.E. Sharpe.

Bughin, J., Hung Byers, A., \& Chui, M. (2011). How social technologies are extending the organization. McKinsey Quarterly: The Online Journal of McKinsey \& Company. Retrieved from http://www.mckinseyquarterly.com/How_social_technologies_are_extending_the_ organization_2888

Burt, R. S. (1992). Structural holes: The social structure of competition. Cambridge, MA: Harvard University Press.

Estes, A. C. (2011). Highlights from the Army's social media handbook. The Atlantic. Retrieved from www.theatlanticwire.com/technology/2011/08/highlights-armys-social-media-handbook/41687/

Estes, C. (2004). Promoting student-centered learning in experiential education. Journal of Experiential Education, 27(2), 141-161.

Franks, P. C. (2010). How federal agencies can effectively manage records created using new social media tools. In Using Technology Series (pp. 54). Washington, DC: IBM Center for the Business of Government.

Fretwell, L. (2010). 10 Entrepreneurs changing the way government works. GovFresh.com. Retrieved from http://govfresh.com/2010/04/10-entrepreneurs-changing-the-way-government-works/

Fugate, C. (2011). Written statement of Craig Fugate, Administrator, Federal Emergency Management Agency, before the Senate Committee on Homeland Security and Governmental Affairs, Subcommittee on Disaster Recovery and Intergovernmental Affairs: Understanding the power of social media as a communication tool in the aftermath of disasters. Retrieved from www.dhs.gov/ ynews/testimony/testimony_1304533264361.shtm

Goodnoe, E. (2005). Wikis make collaboration easier. InformationWeek. Retrieved from www. informationweek.com/shared/printableArticle.jhtml;jsessionid=ZBHP4HNEXGTV5QE1GHPS KHWATMY32JVN?articleID=170100392

Gregory, S. (2010). Cory Booker: The mayor of Twitter and Blizzard superhero. Time.com. Retrieved from www.time.com/time/nation/article/0,8599,2039945,00.html

Kamentz, A. (2010). How an army of techies is taking on City Hall. FastCompany, December/January. Retrieved from www.fastcompany.com/magazine/ $151 /$ icitizen-bonus.html?page $=0 \% 2 \mathrm{C} 2$

Kennedy, D. (2010). The wisdom of crowdsourcing: Far from the nasty comments found on many sites, projects such as SeeClickFix channel participation in constructive, useful ways. The Guardian. Retrieved from www.guardian.co.uk/commentisfree/cifamerica/2010/jun/01/crowdsourcing-internet

Marks, J. (2011). Social media’s role in Arab Spring still unclear. Retrieved from www.nextgov.com/ nextgov/ng_20110916_4696.php

McLean, K. (2005). Research questions of informal learning practitioners: A seriously informal survey. The National Academies Center for Education Board on Science Education, the Status of Research on Learning Science within Informal Education Settings-Think Pieces. Retrieved from www7.nationalacademies.org/bose/Informal_Science_Kathy_McLean_Think_Piece.pdf

Mergel, I. (2010). Informal networks in the public sector using social media applications. Syracuse, NY: Maxwell School of Citizenship and Public Affairs at Syracuse University.

. (2011). The use of social media to dissolve knowledge silos in government. In R. O'Leary, S. Kim, \& D. VanSlyke (Eds.), The future of public administration, public management, and public service around the world (pp. 177-187). Washington, DC: Georgetown University Press. 
. (forthcoming 2012). Social media in the public sector: Participation, collaboration, and transparency in the networked world. San Francisco: Jossey-Bass.

Mergel, I., Lazer, D., \& Binz-Scharf, M. (2008). Lending a helping hand: Voluntary engagement in a network of professionals. International Journal of Learning \& Change, 3(1), 5-22.

Motschnig-Pitrik, R., \& Holzinger, A. (2002). Student-centered teaching meets new media: Concept and case study. Educational Technology \& Society, 5(4), 160-172.

Neubauer, B. J., Hug, R. W., Hamon, K. W., \& Stewart, S. K. (2011). Using personal learning networks to leverage communities of practice in public affairs education. Journal of Public Affairs Education, 17(1), 9-25.

Obama, B. (2009). Transparency and open government: Memorandum for the heads of executive departments and agencies. Whitehouse Blog. Retrieved from www.whitehouse.gov/the_press_office/ TransparencyandOpenGovernment/

O'Leary, R. (1997). The great man theory of teaching is dead. Journal of Public Affairs Education, 3(2), $127-133$.

(2002). Advice to new teachers: Turn it inside out. PSOnline, March, 91-92.

Orlando, J. (2011). Wikis in the classroom: Three ways to increase student collaboration. Faculty Focus: Focused on Today's Higher Education Professional. Retrieved from www.facultyfocus.com/articles/ teaching-with-technology-articles/wikis-in-the-classroom-three-ways-to-increase-student-collaboration/

Oxley, A. (2011). A best practices guide for mitigating risk in the use of social media. Strengthening Cybersecurity Series. Retrieved from www.businessofgovernment.org/report/best-practices-guidemitigating-risk-use-social-media

Public Law 111-274. (2010). Plain Language Act, 124 STAT. 2861, 124 STAT. 2863.

Schweik, C., Mergel, I., Sanford, J., \& Zhao, J. (2011). Toward open public administration scholarship. Journal of Public Administration Research \& Theory, 21(Supplement 1-Minnowbrook III: A Special Issue), i175-i198.

U.S. General Services Administration (GSA). (2010). Landmark agreements clear path for government new media (GSA 10572). Retrieved from www.gsa.gov/portal/content/103496

U.S. Government Accountability Office (GAO). (2011). Social media: Federal agencies need policies and procedures for managing and protecting information they access and disseminate. Washington, DC. Retrieved from http://www.gao.gov/products/GAO-11-605

Veen, V. (2009). San Jose, Calif.'s Wikiplanning project on course. GovTech. Retrieved from www. govtech.com/gt/719878? topic $=290174$

Dr. Ines Mergel is assistant professor of Public Administration and International Affairs and a senior research associate at the Center for Technology and Information Policy (CTIP) at the Maxwell School of Citizenship and Public Affairs, Syracuse University. She teaches classes on social media management and public organizations and management in the Master of Public Administration Program. Her research focuses on the adoption and diffusion of social media applications in the public sector. Her thoughts on the use of social media can be found on her blog: http://inesmergel.wordpress.com and on Twitter @inesmergel. 
I. Mergel

Appendix

Full Course Syllabus for “Government 2.0” Class

For frequent updates, please visit:

http://faculty.maxwell.syr.edu/iamergel/government2-0.htm

\begin{tabular}{|l|l|}
\hline Week: & $\mathbf{1}$ \\
\hline Subject: & $\begin{array}{l}\text { Introduction: } \\
\text { Government 2.0: A new mandate in the public sector } \\
\text { Course schedule, readings, expectations }\end{array}$ \\
\hline
\end{tabular}

- Bretschneider, S. I., \& Mergel, I. (2010). Technology and Public Management Information Systems: Where have we been and where are we going? In D. C. Menzel \& H. J. White (Eds.), The state of public administration: Issues, problems and challenges (pp. 187203). New York: M.E. Sharpe.

- O’Reilly, T. (2009). Gov 2.0: A Promise of Innovation. In J. Goetze \& C. B. Pedersen (Eds.), State of the eUnion: Government 2.0 and onwards (pp. 29-32). Bloomington, IN: AuthorHouse.

- Ressler, S. (2009). The Emergence of Gov 2.0: From GovLoop to the White House. In J. Goetze \& C. B. Pedersen (Eds.), State of the eUnion: Government 2.0 and onwards (pp. 43-48). Bloomington, IN: AuthorHouse.

- Thomson, C. (2008, Sept. 7). Brave New World of digital intimacy. New York Times.

\begin{tabular}{|l|l|}
\hline Week: & $\mathbf{2}$ \\
\hline Subject: & $\begin{array}{l}\text { Social media ecosystem } \\
\text { Introduction to social media applications (Part I) }\end{array}$ \\
\hline
\end{tabular}

\section{Tools \& student presentations:}

- Blogging \& RSS feeds

- Microblogging

- Netherland, W., \& McCroskey, C. (2010). Case Study: Tweet Congress. In D. Lathrop \& L. Ruma (Eds.), Open governmentcollaboration, transparency, and participation in practice (pp. 177-182). Sebastopol, CA: O’Reilly Media.

- Twitter.com: Science for a Changing World, USGS Twitter business case.

- Wyld, D. (2007). The blogging revolution: Government in the age of Web 2.0. IBM Center for the Business of Government report. 


\begin{tabular}{|l|l|}
\hline Week: & $\mathbf{3}$ \\
\hline Subject: & $\begin{array}{l}\text { Barriers and drivers for the adoption of social media in the public sector } \\
\text { Introduction to social media applications (Part II) }\end{array}$ \\
\hline
\end{tabular}

\section{Tools \& student presentations:}

- Online social networks: Facebook, LinkedIn, GovLoop

- Content sharing: Photo sharing sites, YouTube

- Boyd, D. M., \& Ellison, N. B. (2007). Social network sites:

Definition, history, and scholarship. Journal of Computer-Mediated Communication, 13(1); available online.

- Mergel, I. \& Schweik, C. (2012). Web 2.0 in the public sector. In E. Downey \& M. Jones (Eds.), Public service, governance and Web 2.0 technologies (pp. 269-293). IGI-Global. doi:10.4018/978-1-46660071-3.

- $\quad$ Rainie, L., Purcell, K., \& Smith, A. (2011). The social side of the Internet. Pew Internet and American Life Project.

- Samuel, A. (2009). Waiting for Government 2.0: Why do public agencies take so long to embrace social media? In J. Goetze \& C. B. Pedersen (Eds.), State of the eUnion: Government 2.0 and onwards (pp. 111-124). Bloomington, IN: AuthorHouse.

\begin{tabular}{|l|l|}
\hline Week: & $\mathbf{4}$ \\
\hline Subject: & $\begin{array}{l}\text { Organizational institutions for the use of social media in government } \\
\text { Guest speaker: Rachel Flagg, GSA, Center for Excellence in Digital Government, } \\
\text { HowTo.gov }\end{array}$ \\
\hline
\end{tabular}

- Aitoro, J. R. (2009, March 25). GSA signs deals for agencies to use social networking sites. NextGov; available online.

- Government Accountability Office (GAO). (2011). Challenges in federal agencies' use of Web 2.0 technologies.

- Oxley, A. (2011). A best practices guide for mitigating risk in the use of social media. IBM Center for the Business of Government; report available online.

- Sproull, L., \& Kiesler, S. (1986). Reducing social context cues: Electronic mail in organizations. Management Science, 32(11), 1492-1512. 


\begin{tabular}{|l|l|}
\hline Week: & 5 \\
\hline Subject: & $\begin{array}{l}\text { America 2.0: Transforming lessons learned from the campaign to government } \\
\text { operations }\end{array}$ \\
\hline
\end{tabular}

- Barr, A. (2008). 2008 turnout shatters all records. Politico, November 5, 2008.

- Senior, J. (2009, August 2). The message is the message: Barack Obama's ubiquitous appearances as professor-in-chief, preacher-inchief, father-in-chief, may turn out to be the most salient feature of his presidency. New York Magazine.

- Sifry, M. (2010). "You can be the eyes and ears": Barack Obama and the wisdom of the crowds. In D. Lathrop \& L. Ruma (Eds.), Open government-Collaboration, transparency, and participation in practice (pp. 115-122). Sebastopol, CA: O’Reilly Media.

- Wallsten, P. (2009, Jan. 14). Retooling Obama's campaign machine for the long haul. LA Times.

\begin{tabular}{|l|l|}
\hline Week: & $\mathbf{6}$ \\
\hline Subject: & $\begin{array}{l}\text { Social media policies and strategies in the public sector } \\
\text { (organizational \& personal approaches) } \\
\text { Guest speaker: Bill Greeves, Director of Communication, Roanoke County (VA) }\end{array}$ \\
\hline
\end{tabular}

- Dunn, Brian J. (2010). How I did it: Best Buy's CEO on learning to love social media. Harvard Business Review.

- Harvard Business Review Analytic Service Report. (2010). The new conversation: Taking social media from talk to action. Harvard Business Review. Retrieved from http://hbr.org/product/the-newconversation-taking-social-media-from-talk/an/10815-PDF-ENG

- Mergel, I. (2010). Government 2.0 revisited: Social media strategies in the public sector. American Society for Public Administration, 33(3), $7 \& 10$.

\begin{tabular}{|l|l|}
\hline Week: & 7 \\
\hline Subject: & Social media records: Archiving, scheduling, management \\
\hline
\end{tabular}

- Franks, P. C. (2011). How federal agencies can effectively manage records created using new social media tools. IBM Center for the Business of Government.

- NARA Bulletin 2011-02: Guidance on managing records in Web 2.0/social media platforms. 


\begin{tabular}{|l|l|}
\hline Week: & $\mathbf{8}$ \\
\hline Subject: & $\begin{array}{l}\text { Reuse of public sector information } \\
\text { Data.gov, mobile applications, civic hackers } \\
\text { Guest speaker: Mark Headd, Senior Developer Evangelist, Voxeo Labs \& Founder } \\
\text { Civic Innovations }\end{array}$ \\
\hline
\end{tabular}

- Lakhani, K., Austin, R. D., \& Yi, Y. (2010). Data.gov, Harvard Business School, Case study. Available online only—no paper or digital print possible.

- USA: http://www.data.gov

- UK: http://data.gov.uk/

- Australia: http://data.gov.au/

- The Guardian. (2011, Dec. 12). Government computing: EU gets open data strategy.

\begin{tabular}{|l|l|}
\hline Week: & 9 \\
\hline Subject: & $\begin{array}{l}\text { Distributed Democracy 2.0: SeeClickFix.com } \\
\text { Guest speaker Ben Berkowitz, CEO SeeClickFix.com }\end{array}$ \\
\hline
\end{tabular}

- Bovaird, T., Loeffler, E., \& Downe, J. (2009): Co-production of public services and policies: The role of emerging technologies. In J. Goetze \& C. B. Pedersen (Eds.), State of the eUnion: Government 2.0 and onwards (pp. 263-280). Bloomington, IN: AuthorHouse.

- Caddy, J. (2009). Focusing on citizens. In J. Goetze \& C. B. Pedersen (Eds.), State of the eUnion: Government 2.0 and onwards (pp. 213-222). Bloomington, IN: AuthorHouse.

- King, S. F., \& Brown, P. (2007, Dec. 10-13). Fix my street or else: Using the Internet to voice local public service concerns. CEGOV2007, Macao.

- Smith, A. (2011). Neighbors Online, Pew Internet and American Life Project; available online.

\begin{tabular}{|l|l|}
\hline Week: & $\mathbf{1 0}$ \\
\hline Subject: & $\begin{array}{l}\text { Open Innovation in the Public Sector } \\
\text { Guest speaker: Dustin Haisler, Director, Spigit.com }\end{array}$ \\
\hline
\end{tabular}

- Chesbrough, H. (2003). The era of open innovation. MIT Sloan Management Review, 44(3), 35-41.

- McKinsey \& Company. (2009). And the winner is... Capturing the promise of philanthropic prizes; available online.

- Mergel, I. (2011, October). Crowdsourced ideas make participating in government cool again. American Society for Public Administration, 34(4), $4 \& 6$. Special Issue: From Bureaucratic to Cool: A Call for Public Service. 


\begin{tabular}{|l|l|}
\hline Week: & $\mathbf{1 1}$ \\
\hline Subject: & $\begin{array}{l}\text { Collaboration across organizational boundaries with the use of social media } \\
\text { Wikis in government, knowledge and project management, sharing }\end{array}$ \\
\hline
\end{tabular}

\section{Tools \& student presentations:}

- Carafano, J. J. (2011, 1st quarter). Mastering the art of wiki: Understanding networking and national security. Joint Force Quarterly, Issue 60, 73-78.

- McAffee, A. (2005). Will web services really transform collaboration? MIT Sloan Management Review, 78-84.

- Mergel, I. (2011, May). Using wikis in government: A guide for using and maintaining wikis in the public sector. IBM Center for the Business of Government, Report "Using Technology" Series.

\begin{tabular}{|l|l|}
\hline Week: & $\mathbf{1 2}$ \\
\hline Subject: & Measuring social media impact in the public sector \\
\hline
\end{tabular}

- Hoffman, D. L., \& Fodor, M. (2010). Can you measure the ROI of your social media marketing? MIT Sloan Management Review, 52(1), 41-49.

- Mergel, I. (2012). Measuring the effectiveness of social media tools in the public sector. In E. Downey \& M. Jones (Eds.), Public service, governance and Web 2.0 technologies (pp. 48-64). IGI-Global, doi:10.4018/978-1-46660-071-3.

\begin{tabular}{|l|l|}
\hline Week: & 13 \\
\hline Subject: & The future of social media in government \\
\hline
\end{tabular}

\begin{tabular}{|l|l|}
\hline Week: & 14 \\
\hline Subject: & $\begin{array}{l}\text { Final project presentations } \\
\text { Wrap up }\end{array}$ \\
\hline
\end{tabular}

